\title{
Effect of Planting Density and Mulching on Vegetative and Reproductive Parameters of Mango (Mangifera indica L.) cv. Alphonso
}

\author{
D. Kiranshankar*, Athani, S.I. Allolli, T.B. Ramachandra Naik, K. Naik, \\ R.B. Chavan, M.L. Praveen Jholgikar and P.M. Sampath \\ University of Horticultural Sciences, Bagalkot - 587 102, India \\ *Corresponding author
}

\begin{tabular}{|l|}
\hline K e y w o r d s \\
Mangifera indica, \\
$\begin{array}{l}\text { Alphonso, High } \\
\text { density planting and } \\
\text { Mulching }\end{array}$ \\
\hline Article Info \\
\hline $\begin{array}{l}\text { Accepted: } \\
\text { 18 April } 2018 \\
\text { Available Online: } \\
10 \text { May } 2018\end{array}$ \\
\hline
\end{tabular}

\section{A B S T R A C T}

Mango (Mangifera indica L.) is the leading fruit crop of India, belonging to family Anacardiaceae. The demand for mango fruit is growing annually and the requirement is not met with existing rate of production. So, there is good scope for increasing the area and productivity of mango in the country. One of the strategies to achieve this is by adopting high density planting, to increase the productivity per unit area. Hence, an investigation carried out with four different spacing i.e. $\mathrm{D}_{1}-2.5 \times 2.5 \mathrm{~m}(1600$ plants/ ha $), \mathrm{D}_{2}-5.0 \times 2.5$ $\mathrm{m}\left(800\right.$ plants/ ha), $\mathrm{D}_{3^{-}} 5.0 \times 5.0 \mathrm{~m}$ (400 plants/ ha), $\mathrm{D}_{4^{-}} 7.5 \times 5.0 \mathrm{~m}$ (267 plants/ ha) with three different combinations of mulching i.e. $\mathbf{M}_{1}$ - Paddy straw mulch, $\mathbf{M}_{2}$ - Plastic mulch (50 micron thickness), $\mathrm{M}_{3^{-}}$Without mulch (control) and their interaction was studied. The experimental results reveals that the plant with spacing of $5.0 \times 5.0 \mathrm{~m}$ showed highest growth increment in terms of height $(47.02 \mathrm{~cm})$ and plant spread $(\mathrm{E}-\mathrm{W})(38.17 \mathrm{~cm})$ and the plants with the spacing of $7.5 \times 5.0$ m showed highest increment in stem girth $(16.70 \mathrm{~mm})$, canopy volume $\left(2.20 \mathrm{~m}^{3}\right)$ and plant spread $(\mathrm{N}-\mathrm{S})(22.44 \mathrm{~cm})$. The plastic mulching resulted in highest increment in plant height $(45.86 \mathrm{~cm})$, stem girth $(17.51 \mathrm{~mm})$, canopy volume $\left(1.57 \mathrm{~m}^{3}\right)$ and plant spread in North-South $(39.01 \mathrm{~cm})$ and East-West $(39.38 \mathrm{~cm})$ directions compared to other mulches. The data on per cent fruit set revealed that the plants with spacing of $7.5 \times 5.0 \mathrm{~m}$ showed significantly highest fruit set per cent $(0.243 \%)$ which was on par with spacing at $5.0 \times 5.0 \mathrm{~m}$. Plastic mulching $\left(\mathrm{M}_{2}\right)$ showed increase in number of active roots which indirectly helps in increase in panicle length $(39.76 \mathrm{~cm})$, panicle breadth $(20.62 \mathrm{~cm})$, number of panicles (62) and vigorous in plant growth. The interaction effect revealed that, spacing of $7.5 \times 5.0$ m with plastic mulch $\left(\mathrm{D}_{4} \mathrm{M}_{2}\right)$ showed maximum panicle length $(41.33 \mathrm{~cm})$ and per cent fruit set $(0.3 \%)$, whereas $5.0 \times 5.0 \mathrm{~m}$ with plastic mulch $\left(\mathrm{D}_{3} \mathrm{M}_{2}\right)$ showed highest panicle breadth $(21.76 \mathrm{~cm})$ and number of panicles per plant $(78)$.

\section{Introduction}

Mango (Mangifera indica L.) is the leading fruit crop of India, belonging to family Anacardiaceae and cultivated in tropical and subtropical regions of the world. It is considered to be a King of fruits because of its delicious taste, excellent flavor and attractive fragrance. Besides, it is rich in vitamin A and C. In India, mango occupies 34.9 per cent of the total area under fruits comprising of 2.51 million hectares, with a total production of 
18.43 million tonnes. Although, India is the largest mango producing country, accounting about 60 per cent of the world production (Anon., 2014), the export of fresh fruit is limited to only Alphonso and Dashehari varieties. India's share in the world mango market is about 15 per cent and accounts for 40 per cent of the total fruit export from the country.

The demand for mango fruit is growing annually and the requirement is not met with existing rate of production. So, there is good scope for increasing the area and productivity of mango in the country. One of the strategies to achieve this is by adopting high density planting, to increase the productivity per unit area. Hence, an investigation to know the effect of planting density and mulching on vegetative and reproductive parameters of mango mango (Mangifera indica L.) cv. Alphonso" was carried out.

\section{Materials and Methods}

The investigation to know the effect of planting density and mulching on vegetative and reproductive parameters of mango mango (Mangifera indica L.) cv. Alphonso was carried out in the mango orchard of the Regional Horticulture Research and Extension Center, Dharwad (University of Horticultural Sciences, Bagalkot) during July-2013 to June2015. The Regional Horticultural Research and Extension Center is situated at $15^{\circ}-16^{\text {' }}$ Northern latitude, $70^{\circ}-07^{\prime}$ Eastern longitude and at an altitude of $678 \mathrm{~m}$ above the mean sea level. The soil of the experimental plot is red sandy loam, reddish brown colour, well drained having moderate water holding capacity. Dharwad has a transitional type of climate, which received the total rainfall of $733.8 \mathrm{~mm}$ during the year 2013-2014, whereas the rainfall was $761.3 \mathrm{~mm}$ during the period of study $2014-2015$.
Three year old mango orchard cv. Alphonso established during 2010 was selected for the experiment. Alphonso is one of the most preferred varieties of mango and is grown mainly in the western part of India including the Konkan region of India. Alphonso is generally referred to as 'Hapus' in Maharashtra and Gujarat. In Karnataka, it also popularly known as Appus, Badami, Gundu. It is used to make sweets, candies smoothies and mango drinks. Fruits are orange-yellow in colour, medium-sized and oval/oblong in shape. The average fruit length is $11.6 \mathrm{~cm}$, width is 9.3 $\mathrm{cm}$, weighing $300-450 \mathrm{~g}$. The peel is thin and smooth, pulp is firm to soft, low in fibre, pulp is yellow and has pleasant taste and good eating quality. The seed is mono-embryonic large woody stone. The fruit matures in early to mid-season. The tree is moderately large and vigorous with a broadly rounded dense canopy. The details of the Experimental design with Factorial randomized design with twelve treatments namely Factor - I - Plant density $\left(\mathrm{D}_{1^{-}} 2.5 \times 2.5 \mathrm{~m}\right.$ (1600 plants/ ha), $\mathrm{D}_{2}$ $5.0 \times 2.5 \mathrm{~m}(800$ plants/ ha $), \mathrm{D}_{3^{-}} 5.0 \times 5.0 \mathrm{~m}$ (400 plants/ ha), $\mathrm{D}_{4^{-}} 7.5 \times 5.0 \mathrm{~m}$ (267 plants/ ha)) and Factor - II - Mulching ( $\mathrm{M}_{1}$ - Paddy straw mulch, $\mathrm{M}_{2^{-}}$Plastic mulch (50 micron thickness) and $\mathrm{M}_{3^{-}}$Without mulch (control) with three replication in 1.5 hectare net experimental plot area.

The vegetative growth parameters viz., Plant height $(\mathrm{cm})$, Stem girth $(\mathrm{mm})$, Canopy volume $\left(\mathrm{m}^{3}\right)$, Plant spread-NS and EW $(\mathrm{cm})$, Number of primary branches, Number of secondary branches, Number of tertiary branches were measured at 90 days interval after imposition of treatments, in five representative plants in each treatment and average was calculated. For all the vegetative growth only incremental growth is given in results and were discussed, whereas the vegetative growth parameters was recorded at three months interval and is given in Appendix I. 
Plant height was recorded from base to the top of the plant by using a meter scale and it was expressed in centimeters. Five tagged plants were used to measure the trunk girth. Girth was measured one foot above the ground level by using a verniar calipers at coller region and expressed in milimeters. The canopy volume in all three directions viz. North-South, EastWest and height from first branch to top of the plant are recorded. Canopy volume was calculated at 90 days interval, Canopy volume (m) ${ }^{3}=4 / 3 a^{2} b$, Where, $a=$ Half of the plant height, $b=$ Average of east-west and northsouth plant spread Westwood et al., (1963).

The plant spread was measured by taking horizontal distance from one end of the canopy to the other end in both directions viz. North-South and East-West with the help of meter scale and it was expressed in centimeters. The number of tertiary branches was recorded by counting the branches developed on secondary branches.

The reproductive parameters viz., Panicle length $(\mathrm{cm})$, Panicle breadth $(\mathrm{cm})$, Number of panicles/plant and per cent fruit set were recorded from flower emergence to fruit harvest. The length of panicle at full growth stage was noted at anthesis and it was measured from the shoot apex to that of panicle apex and an average of ten observations per plant was taken for computing the mean and the value was expressed in centimeter $(\mathrm{cm})$. The breadth of the panicle was measured at the widest part of panicle at anthesis stage and expressed in centimeters. The number of panicles per plant was recorded by counting panicles physically in five tagged plants and it was expressed in numbers. It was calculated by dividing number of fruit set, by number of flower counted and expressed in percentage. Fruit set $\%=\frac{\text { Number of fruit set }}{\text { Number of flowers appeared }} \times 100$ fapy diameter into the rows.

\section{Results and Discussion}

The pooled data with respect to plant height showed increase in height with decrease in planting density. At the end of experiment the plant with spacing of $5.0 \times 5.0 \mathrm{~m}$ showed highest growth increment in terms of height $(47.02 \mathrm{~cm})$ and plant spread $(\mathrm{E}-\mathrm{W})(38.17 \mathrm{~cm})$ and the plants with the spacing of $7.5 \times 5.0 \mathrm{~m}$ showed highest increment in stem girth (16.70 $\mathrm{mm})$, canopy volume $\left(2.20 \mathrm{~m}^{3}\right)$ and plant spread $(\mathrm{N}-\mathrm{S})(22.44 \mathrm{~cm})$. The plants under spacing of $7.5 \times 5.0$ and $5.0 \times 5.0 \mathrm{~m}$ were found on par with each other. These results are in conformity with the earlier findings of Ram and Sirohi (1991) and Nath et al., (2007) in mango who reported reduction in vegetative growth variables in mango trees grown under increased planting density in 'Dashehari' and 'Amrapali' varieties.

Policarpo et al., (2006), Johnson and Robinson (2000) reported that the possible explanation is the competition among the plants for water, soil, nutrients and mainly for light since under higher planting density, plant canopies overlap into the rows, reducing light penetration on leaves. Consequently, great part of the canopy contributes little or nothing to the synthesis of carbohydrates necessary for growth.

There has been reduced stem girth due to high density planting in mango and it was confirmed by all studies (Nath et al., 2007; Singh et al., 2007 and Nakamura et al., 2008) in mango. However, the way that the plants are trained is also important, which may accentuate or no apical dominance and, consequently, growth decreased as the planting density increases.

In higher planting densities, canopy diameter between rows showed less reduction than 
Mulching in mango has imparted beneficial effect as evidenced by enhanced growth and development. Higher growth under mulched treatments might be due to its favorable effect on weed control. This may be due to many reasons, may be due to reduction in weed population and effective consumption of water. There was complete elimination of weeds under black polyethylene mulch, whereas in unmulched plots weeding was done manually seven times during both years of experimentation. In present investigation the plastic mulching resulted in highest increment in plant height $(45.86 \mathrm{~cm})$, stem girth $(17.51 \mathrm{~mm})$, canopy volume $\left(1.57 \mathrm{~m}^{3}\right)$ and plant spread in North- South $(39.01 \mathrm{~cm})$ and East- West $(39.38 \mathrm{~cm})$ directions compared to other mulches. These results are in agreement with Chakaraborty and Sadhu (1994) and Singh (2005) in mango as they also reported complete elimination of weeds with the use of black polyethylene.

The interaction effect revealed that the treatment $\mathrm{D}_{4} \mathrm{M}_{2}(7.5 \times 5.0 \mathrm{~m}$ spacing with plastic mulch) recorded highest plant height $(52.39 \mathrm{~cm})$, canopy volume $\left(2.72 \mathrm{~m}^{3}\right)$ and plant spread (north - south) $(41.51 \mathrm{~cm})$. And the spacing of $5.0 \times 5.0 \mathrm{~m}$ with plastic mulch $\left(\mathrm{D}_{3} \mathrm{M}_{2}\right)$ showed highest stem girth $(22.57 \mathrm{~mm})$ and plant spread (east-west) $(41.00 \mathrm{~cm})$. Similar results were observed Nath et al., 2007; Singh et al., 2007; Nakamura et al., 2008 in mango.

The reproductive parameters viz., panicle length, panicle breadth, number of panicles per plant and per cent fruit set showed significant differences with different plant densities data clearly indicated that, the trees with spacing of $5.0 \times 5.0 \mathrm{~m}$ showed highest panicle length $(39.33 \mathrm{~cm})$, panicle breadth $(19.69 \mathrm{~cm})$, number of panicles per plant (60.61) which were on par with trees spaced at $7.5 \times 5.0 \mathrm{~m}$. The higher value for reproductive parameters as mentioned above in low density planting might be due to the availability of more floor space for uptake of water, light and nutrients. These results are in conformity with the earlier findings of Virendra et al., (2008) in guava, Biswas et al., (1991) and Ravichandran et al., (2002) in papaya.

The data on per cent fruit set revealed that the plants with spacing of $7.5 \times 5.0 \mathrm{~m}$ showed significantly highest fruit set per cent $(0.243 \%)$ which was on par with spacing at $5.0 \times 5.0 \mathrm{~m}$ which also significantly produced higher number of flowers and their by maximum number of fruits were set as depicted by higher percentage of fruit setting. Similar results were also reported by Virendra et al., (2008) in guava, Chattopadhyay et al., (1985) in banana, Kumar et al., (1989) in papaya and Bisla et al., (1991) in ber. In general, plants showed a low percentage of flowering and subsequently, low fruit yield, indicating some of the problems that a vigorous mango cultivar, such as Alphonso, may have that character in warm tropics (Ramirez and Davenport, 2010). Similar to vegetative variables, reproductive variables (panicle number and length) were also negatively affected by planting density. The smaller the area available to plants, the higher the tendency to decrease the number and percentage of flower shoots and the number and yield of fruit per plant (Table 1).

The consequence of the higher planting densities was the reduction in the number and percentage of flowering shoots. Plants grown under lower planting density produced flowers in all quadrants of the canopy, while those grown under high density (1,600 and 800 plants per hectare) produced flowers only in the two quadrants of the canopy between the rows, but not into the rows. Consequently, there were reductions in the number and yield of fruits per plant. In the planting densities of 400 and 267 plants per hectare, the number of fruits produced represented only about $1 / 4$ of those produced in the lowest planting density, with 267 plants per hectare in mango (Sousa et al., 2012). 
Table.1 The mean performance of mango cv.Alpanso with different spacing in combination of mulching effects with their interaction

\begin{tabular}{|c|c|c|c|c|c|c|c|c|c|c|}
\hline Treatments & $\begin{array}{c}\text { Plant heigh } \\
\text { increment } \\
(\mathrm{cm})\end{array}$ & $\begin{array}{c}\text { Stem girth } \\
\text { increment } \\
\quad(\mathbf{m m})\end{array}$ & $\begin{array}{l}\text { Canopy volume } \\
\text { increment }\left(\mathbf{m}^{3}\right)\end{array}$ & $\begin{array}{l}\text { North-South } \\
\text { increment } \\
\quad(\mathrm{cm})\end{array}$ & $\begin{array}{c}\text { East-West } \\
\text { increment } \\
\quad(\mathrm{cm})\end{array}$ & $\begin{array}{c}\text { Number of } \\
\text { Tertiary } \\
\text { branches }\end{array}$ & $\begin{array}{c}\text { Panicle } \\
\text { length } \\
\text { (cm) }\end{array}$ & $\begin{array}{c}\text { Panicle } \\
\text { breadth } \\
\text { (cm) }\end{array}$ & $\begin{array}{c}\text { Number of } \\
\text { panicles } \\
\text { per plant }\end{array}$ & $\begin{array}{l}\text { Per cent } \\
\text { fruit set } \\
\quad(\%)\end{array}$ \\
\hline \multicolumn{11}{|c|}{ Spacing (D) } \\
\hline $\mathbf{D}_{1}$ & 40.69 & 14.57 & 1.86 & 32.68 & 32.33 & 21.74 & 37.09 & 14.78 & 39.67 & 0.191 \\
\hline $\mathbf{D}_{2}$ & 38.27 & 14.61 & 2.08 & 34.95 & 37.99 & 25.01 & 37.64 & 17.88 & 44.33 & 0.208 \\
\hline $\mathbf{D}_{3}$ & 47.02 & 16.62 & 1.92 & 37.74 & 38.17 & 18.68 & 39.33 & 19.69 & 60.61 & 0.241 \\
\hline $\mathbf{D}_{4}$ & 44.46 & 16.7 & 2.2 & 38.68 & 35.84 & 22.44 & 38.86 & 19.31 & 56.61 & 0.243 \\
\hline S.Em \pm & 0.99 & 0.43 & 0.03 & 0.34 & 0.7 & 0.93 & 0.38 & 0.28 & 0.96 & 0.005 \\
\hline CD@ 5\% & 2.9 & 1.25 & 0.1 & 1.01 & 2.06 & 2.74 & 1.13 & 0.83 & 2.82 & 0.014 \\
\hline \multicolumn{11}{|c|}{ Mulching (M) } \\
\hline $\mathbf{M}_{1}$ & 44.54 & 16.22 & 2.18 & 36.34 & 39.01 & 21.38 & 38.81 & 17.93 & 55.08 & 0.229 \\
\hline $\mathbf{M}_{2}$ & 45.86 & 17.51 & 2.29 & 39.01 & 39.38 & 22.98 & 39.76 & 20.62 & 62 & 0.249 \\
\hline $\mathbf{M}_{3}$ & 37.12 & 13.14 & 1.57 & 32.68 & 29.87 & 21.54 & 36.13 & 15.19 & 33.83 & 0.183 \\
\hline S.Em \pm & 0.86 & 0.37 & 0.03 & 0.3 & 0.61 & 0.81 & 0.33 & 0.25 & 0.83 & 0.004 \\
\hline CD@ $9 \%$ & 2.51 & 1.08 & 0.09 & 0.87 & 1.78 & NS & 0.98 & 0.72 & 2.44 & 0.012 \\
\hline \multicolumn{11}{|c|}{ Interaction } \\
\hline $\mathbf{D}_{1} \mathbf{M}_{1}$ & 41.39 & 15.2 & 1.65 & 32.51 & 37 & 23.86 & 37.85 & 11.5 & 43.5 & 0.201 \\
\hline $\mathbf{D}_{1} \mathbf{M}_{2}$ & 39.33 & 15.35 & 2.32 & 36.01 & 35.5 & 20.32 & 38.21 & 19.35 & 46 & 0.204 \\
\hline $\mathbf{D}_{1} \mathbf{M}_{3}$ & 41.34 & 13.17 & 1.61 & 29.51 & 24.5 & 21.03 & 35.22 & 13.49 & 29.5 & 0.169 \\
\hline $\mathrm{D}_{2} \mathrm{M1}$ & 37.5 & 14.89 & 2.61 & 34.83 & 40.51 & 23.63 & 38.31 & 19.27 & 51 & 0.219 \\
\hline $\mathbf{D}_{2} \mathbf{M}_{2}$ & 39.83 & 15.54 & 2.12 & 37.51 & 44.5 & 28.74 & 38.88 & 19.73 & 51 & 0.226 \\
\hline $\mathbf{D}_{2} \mathbf{M}_{3}$ & 37.49 & 13.39 & 1.52 & 32.5 & 28.97 & 22.67 & 35.72 & 14.65 & 31 & 0.18 \\
\hline $\mathbf{D}_{3} \mathbf{M}_{1}$ & 40.24 & 14.28 & 2.15 & 37.5 & 37.5 & 15.87 & 39.88 & 20.9 & 65.5 & 0.258 \\
\hline $\mathbf{D}_{3} \mathbf{M}_{2}$ & 51.89 & 22.57 & 2.01 & 41 & 41 & 22.85 & 40.61 & 21.76 & 78 & 0.268 \\
\hline $\mathbf{D}_{3} \mathbf{M}_{3}$ & 37.45 & 13 & 1.59 & 34.72 & 36.01 & 17.32 & 37.5 & 16.42 & 38.33 & 0.197 \\
\hline $\mathbf{D}_{4} \mathbf{M}_{1}$ & 43.51 & 20.5 & 2.3 & 40.53 & 41.01 & 22.18 & 39.19 & 20.06 & 60.33 & 0.241 \\
\hline $\mathbf{D}_{4} \mathbf{M}_{2}$ & 52.39 & 16.58 & 2.72 & 41.51 & 36.5 & 20 & 41.33 & 21.66 & 73 & 0.3 \\
\hline $\mathbf{D}_{4} \mathbf{M}_{3}$ & 37.48 & 13.01 & 1.58 & 34 & 30 & 25.14 & 36.07 & 16.22 & 36.5 & 0.188 \\
\hline CV & 8.96 & 9.58 & 7.61 & 8.95 & 10.29 & 8.96 & 6.02 & 9.75 & 9.73 & 10.54 \\
\hline S.Em \pm & 1.71 & 0.74 & 0.06 & 0.6 & 1.22 & 1.62 & 0.67 & 0.49 & 1.67 & 0.008 \\
\hline CD@ $9 \%$ & 5.03 & 2.17 & 0.18 & 1.75 & 3.56 & 4.74 & NS & 1.44 & 4.89 & 0.024 \\
\hline
\end{tabular}


Plastic mulching stimulated the lateral root growth in nutrient-rich upper soil layer in particular. The anatomical structure of roots of mulched trees showed more unicellular and tubular root hairs with prominent conductive tissue compared to non-mulched ones (Singh and Rajan, 2009) mango. Similar results were observed in present investigation in which plastic mulching $\left(\mathrm{M}_{2}\right)$ showed increase in number of active roots which indirectly helps in increase in panicle length $(39.76 \mathrm{~cm})$, panicle breadth $(20.62 \mathrm{~cm})$, number of panicles (62) and vigorous in plant growth.

In the field, stimulation of above ground growth due to mulch might be brought about by warming of the stem by air escaping from the planting hole in the mulch. However, an experiment with black, white, or clear mulch, in which the planting hole was either left uncovered or covered with soil, showed no effect of whole closure on branching even though air temperature near the stem was increased when holes were left uncovered. The results taken together imply that the increased above ground growth observed with mulching is a consequence of enhanced root growth and nutrient uptake. The black polyethylene film (100 $\square$ thick) had an effect on root growth, flowering and fruiting characteristics and nutritional and hydrothermal properties of soil, anatomical changes in roots and pedicel and stomatal behaviour of leaves in mango cultivars Chausa and Langra. Enhancement in flowering (35-50\%) and maximum fruit retention (381.61 and 566.47) was recorded in mulched trees compared to the non-mulched ones Similar results were also reported by Virendra et al., (2008) in guava, Kumar et al., (1989) in papaya and Bisla et al., (1991) in ber.

The interaction effect revealed that, spacing of $7.5 \times 5.0 \mathrm{~m}$ with plastic mulch $\left(\mathrm{D}_{4} \mathrm{M}_{2}\right)$ showed maximum panicle length $(41.33 \mathrm{~cm})$ and per cent fruit set $(0.3 \%)$, whereas $5.0 \mathrm{x}$
$5.0 \mathrm{~m}$ with plastic mulch $\left(\mathrm{D}_{3} \mathrm{M}_{2}\right)$ showed highest panicle breadth $(21.76 \mathrm{~cm})$ and number of panicles per plant (78). This is may be due to the plants spaced at wider spacing with plastic mulching which might have lead to higher reproductive parameters. Similar results were also reported by Pan et al., (2003), Roshan et al., (2011), Virendra et al., (2008) in guava.

\section{References}

Anonymous, 2014, Indian data base http://www.data.gov.in/apedawebsite/ Announcements/List horticultural crops pdf.

Bisla, S. S., Dhiman, B. K. and Chharia, A. S., 1991, Effect of planting distance and severity of pruning on flowering and fruiting behavier of ber (Zizypus mouritiana Lam.) cv. Umran. Haryana J. Hort. Sci., 20: 26-30.

Biswas, B., Sen, S. K. and Maiti, S. C., 1991, Effect of plant density on growth, yield and chemical composition of papaya fruit variety Ranchi. Prog, Hort., 21: 280-284.

Chakaraborty and Sadhu., 1994, Effect of mulch type and colour on growth and yield of tomato. Indian J. Agri. Sci 64: 608-612.

Chattopadhyay, P. K., Bhowmik, D. J., Maiti, S. C. and Bose, T. K., 1985, Optimum planting density for plant and ratoon crops of giant governor Cavendish banana in West Bengal. Indian J. Agric. Sci., 55: 17-21

Johnson and Robinson, 2000, The Colonial Origins of Comparative Development: An Empirical Investigation. The American Economic Review, 91(5): 1369-1401 (Dec., 2001).

Kumar, T. K., Sen, S. K., Bhattacharya, S. P. and Battacharjee, O., 1989, Effect of spacing and variety on plant growth and yield of papaya. Indian Agriculturist. 33: 239-245. 
Nakamura, R., Takeuchi, R., Takata, K., Shimanouchi, K., Abe, Y., Kanai, Y., Ruike, T., Ihara, A., Sakaguchi, K., 2008, TRF4 is involved in polyadenylation of sn RNAs in Drosophila melanogaster. Mol. Cell. Biol. 28(21): 6620-6631.

Nath, V. B. Das, M. Rai., 2007, Standardization of high density planting in mango (Mangifera indica L.) under sub humid Alfisols of Eastern India. Indian J. of Agri. Sci., 77: 3-7.

Pan, X. Y., Wang, G. X., Chan, X. P., 2003, Elevated growth redundancy and size inequality in spring of wheat population mulch with clear plastic film. J. Agri. Sci 40(2): 193-204.

Patel, D.J., 2001, Soil solarisation for management of soil borne plant pat hol. 31: $1-8$

Policarpo, F., Oliveira, M. M. and Comba, J., 2006, Real time relief mapping on arbitrary polygonal surfaces. In Proc. of ACM Symposium on Interactive 3D Graphics and Games, pages 155-162.

Ram, S. and Sirohi, S.C., 1991, Feasibility of high density orcharding in Dashehari mango. Acta Hort., 291: 207-212.

Ramirez, F. and Davenport, T. L., 2010, Mango (Mangifera indica L.) flowering physiology. Sci. Hort., 126(2): 65-72.

Ravichandran, V., Kumar, N., Jeyakumar, P., Soorianathasundaram, K. and Vijayakumar, R. M. 2002, Influence of planting density and nutrient levels on growth and yield of papaya cv. Co- 2 . South Indian Hort. 35(1): 22-24.

Roshan, R., Singh, R., Singh, D., Gupta, R., 2011, Influnce of covers and mulching of leaf interaction of leaf physiology, fruit yield and albinium incidence in sweet charles strawberry. 63(2): 103110

Singh, R., 2005, Influence of mulching on growth and yield of tomato (Lycopersicon esculentum) in north India plains. VegeTable Sci., 32(1): 5558.

Singh, V. K. and Rajan, S., 2009, Changes in photosynthetic rate, specific leaf weight and sugar contents in mango (Mangifera indica L.). Open HorticultureJ., 2: 4043.

Singh, V. K. and Singh. G., 2007, Photo synthetic efficiency, canopy micro climate and yield of rejuvenated guava trees. Acta Hort., 37(342): 22-28.

Sousa, Carlos Antônio Ferreira De; Cavalcanti, Maria Irisvalda Leal Gondim; Vasconcelos, Lúcio Flavo Lopes; Sousa, Humberto Umbelino De; Ribeiro, Valdenir Queiroz; Silva and José Algaci Lopes Da., 2012, 'TommyAtkins' Mango Trees Subjected to High Density Planting in Subhumid Tropical Climate. Agropecuária Brasileira, 47(1): 36-43.

Virendra, S. Ahalawat, T. R. and Barad, A. V., 2008, Growth, flowering, fruiting and yield of guava (Psidium guajava L.) cv. 'Sardar'grown under high density planting systems as influenced by various organic and inorganic sources. Asian J. Hort., 3(2): 382-385.

Warnick, J. P., Chase, C. A., Rosskopt., E. W., Weed suppression with hydra mulching, a biodegradable liquid paper mulching development. 22(4): 216-223.

\section{How to cite this article:}

Kiranshankar, D., Athani, S.I. Allolli, T.B. Ramachandra Naik, K. Naik, R.B. Chavan, M.L. Praveen Jholgikar and P.M. Sampath. 2018. Effect of Planting Density and Mulching on Vegetative and Reproductive Parameters of Mango (Mangifera indica L.) cv. Alphonso. Int.J.Curr.Microbiol.App.Sci. 7(05): 2259-2265. doi: https://doi.org/10.20546/ijcmas.2018.705.262 